\title{
Activation of adenosine ${ }_{1}\left(A_{1}\right)$ receptors suppresses head shakes induced by a serotonergic hallucinogen in rats
}

\author{
Gerard J. Marek \\ Abbott Laboratories, Abbott Park, IL, USA
}

\begin{abstract}
Modulation of glutamatergic neurotransmission by metabotropic glutamate2/3 (mGlu2/3) receptor agonists effectively treats seemingly diverse neuropsychiatric illness such as generalized anxiety disorder and schizophrenia. Activation of adenosine $\mathrm{A}_{1}$ heteroceptors, like mGlu2 autoreceptors, decreases glutamate release in the medial prefrontal cortex (mPFC) and other limbic brain regions. Previously, we have reported electrophysiological, neurochemical and behavioral evidence for interactions between the 5-hydroxytryptamine $2 \mathrm{~A}\left(5-\mathrm{HT}_{2 \mathrm{~A}}\right)$ and $\mathrm{mGlu} 2 / 3$ receptors in the $\mathrm{mPFC}$. The present studies were designed to investigate the effects in rats of adenosine $\mathrm{A}_{1}$ receptor activation/ blockade on a behavior modulated by $5-\mathrm{HT}_{2 \mathrm{~A}}$ receptor activation/blockade in the $\mathrm{mPFC}$ : head shakes induced in the rat by phenethylamine hallucinogens. An adenosine $\mathrm{A}_{1}$ receptor agonist, $\mathrm{N}^{6}$ -

cyclohexyladenosine (CHA) suppressed head shakes induced by activation of 5- $\mathrm{HT}_{2 \mathrm{~A}}$ receptors with the phenethylamine hallucinogen ( \pm )-2,5-dimethoxy-4-iodoamphetamine hydrochloride (DOI). An adenosine A1 receptor antagonist, 8-cyclopentyl-1,3-dipropylxanthine (DPCPX), enhanced DOIinduced head shakes and blocked the suppressant action of an adenosine $\mathrm{A}_{1}$ receptor agonist on DOIinduced head shakes. Thus, the pattern of activity for an agonist and antagonist at the adenosine A1 receptor with respect to modulating DOI-induced head shakes is similar to the pattern observed with mGlu2/3 receptor agonists and antagonists. These novel observations with an adenosine $\mathrm{A}_{1}$ receptor agonist suggests that this pharmacological action could contribute to antipsychotic effects in addition to thymoleptic effects.
\end{abstract}

\section{Keywords}

head shakes; phenethylamine hallucinogens; DOI; adenosine; glutamate; medial prefrontal cortex

\section{Introduction}

Activation of metabotropic glutamate $2 / 3$ (mGlu2/3) receptors by orthosteric agonists recently has been shown to be an effective therapeutic approach for neuropsychiatric illness with suspected divergent etiology and pathophysiology such as generalized anxiety disorder and schizophrenia (Dunayevich et al., 2008; Patil et al., 2007). Blockade of neurotransmitter release, especially glutamate, via activation of $\mathrm{mGlu2}$ autoreceptors is a prominent role played by mGlu2/3 receptor agonists (Cartmell et al., 2000b; Schoepp, 2001). Activation of mGlu2

\footnotetext{
(C) 2009 Elsevier Ltd. All rights reserved.

Correspondance : Abbott Laboratories, Neuroscience Development, GPRD R48B AP04-1, 100 Abbott Park Road, Abbott Park, IL 60064-6075, Email: E-mail: gerard.marek@ abbott.com, Phone: (847)937-4453, FAX : (847)937-0745.

Publisher's Disclaimer: This is a PDF file of an unedited manuscript that has been accepted for publication. As a service to our customers we are providing this early version of the manuscript. The manuscript will undergo copyediting, typesetting, and review of the resulting proof before it is published in its final citable form. Please note that during the production process errors may be discovered which could affect the content, and all legal disclaimers that apply to the journal pertain.
} 
receptors within the medial prefrontal cortex (mPFC) may decrease glutamate release induced by activation of cortical 5- $\mathrm{HT}_{2 \mathrm{~A}}$ receptors or the disinhibitory effects of NMDA receptor antagonists on local circuit interneurons in the hippocampus or mPFC (Jodo et al., 2004; Homayoun and Moghaddam, 2007). Thus, activation of mGlu2 autoreceptors appears to attenuate the electrophysiological, neurochemical and behavior effects of 5- $\mathrm{HT}_{2 \mathrm{~A}}$ receptor activation or NMDA receptor blockade (Benneyworth et al., 2007; Carli et al., 2004; Cartmell et al., 2000a; Galici et al., 2005; Gewirtz and Marek, 2000; Higgins et al., 2003; Homayoun et al., 2005; Marek et al., 2000; Moghaddam and Adams, 1998; Muschamp et al., 2004).

Activation of adenosine $A_{1}$ receptors, like mGlu2 receptors, is known to decrease glutamate release in many limbic-related brain regions, as measured by electrophysiological recordings from layer V pyramidal cells of the medial prefrontal cortex (Brand et al., 2001; Marek et al., 2000; Stutzman et al., 2001). Previous preclinical in vivo testing with adenosine $\mathrm{A}_{1}$ receptor agonists has supported potential anxiolytic (Florio et al., 1998; Jain et al., 1995) and antipsychotic (Andine et al., 1999; Browne and Welch, 1982; Florio et al., 1998; Gotoh et al., 2002; Jain et al., 1995; Sills et al., 1999) action.

Therefore, the present studies were designed to investigate the effects of adenosine $\mathrm{A}_{1}$ receptor activation/blockade with respect to a behavior which may be mediated and/or modulated by increased glutamate release in the mPFC. Since head shakes induced by phenethylamine hallucinogens such as (1-(2,5,dimethoxy-4-iodophenyl))-2-aminopropane (DOI) appear to be mediated by activation of $5-\mathrm{HT}_{2 \mathrm{~A}}$ receptors in the $\mathrm{mPFC}$ and are also suppressed by activation of mGlu2 autoreceptors, these DOI-induced head shakes were chosen as the first in vivo model system to test in the rat (Benneyworth et al., 2007; Gewirtz and Marek, 2000; Gonzalez-Maeso et al., 2007; Klodzinska et al., 2002; Willins and Meltzer, 1997). Another justification supporting DOI-induced head shakes as a model system is that in vivo microdialysis studies have suggested that systemic administration of phenethylamine hallucinogenic drugs is associated with increased extracellular glutamate in the $\mathrm{mPFC}$ and somatosensory cortex (Muschamp et al., 2004; Scruggs et al., 2003). Consistent with these studies in rodents, administration of phenethylamine hallucinogens have also been demonstrated to increase regional cerebral blood flow in the $\mathrm{mPFC}$ and other neocortical areas in healthy human volunteers (Vollenweider et al., 1997).

Therefore, in this study, we examined the effects of the adenosine $A_{1}$ receptor agonist $\mathrm{N}^{6}$ cyclohexyladenosine (CHA) on DOI-induced head shakes to examine a behavior induced by activation of 5- $\mathrm{HT}_{2 \mathrm{~A}}$ receptors in the rat prefrontal cortex. The suppressant action of CHA on DOI-induced head shakes was tested for pharmacological specificity using the adenosine $\mathrm{A}_{1}$ receptor antagonist 8-cyclopentyl-1,3-dipropylxanthine (DPCPX or PD116,948). The pharmacology of adenosine $A_{1}$ receptor ligands (Bruns et al., 1987; Salvatore et al., 1993) with respect to DOI-induced head shakes is consistent with previous preclinical predictions that adenosine A1 agonists might demonstrate antipsychotic action.

\section{Materials and Methods}

\subsection{Subjects}

Male Sprague-Dawley rats $(\mathrm{n}=102)$ weighing between $150-300 \mathrm{~g}$ at the initial behavioral testing were used (Harlan, Indianapolis, IN). They were housed in suspended stainless wire cages $(18 \times 36 \times 20 \mathrm{~cm})$ with two to four rats occupying each cage. The colony room was maintained at $20^{\circ} \mathrm{C}$ and relative humidity $(60 \%)$. The room was illuminated $12 \mathrm{hr} / \mathrm{day}(07: 00$ 19:00). All rats had free access to laboratory chow (Teklad 4\% Rat Diet) and water except during experimental sessions. All animals were treated in accord with the National Institutes of Health's Guide for the Care and Use of Laboratory Animals. In addition, all protocols were approved by the Yale University Animal Care and Use Committee. 


\subsection{Behavioral observations}

All experiments were performed between 9:00 and 16:00. The animals were transferred to a clear polycarbonate cage $(43 \times 21.5 \times 20 \mathrm{~cm})$ with a sawdust-covered floor. All the rats were habituated to the testing environment with a saline injection at least several days prior to the first DOI/vehicle, CHA/vehicle or DPCPX/vehicle injection. The animals were observed during consecutive 5 min periods for a total of 30 min following the DOI injection. In addition to counting each head shake response, forward locomotion (movement from one end to the other end of the cage was scored as one cross), and rearing (raising up on hind limbs) was also recorded.

\subsection{Statistical analysis}

A one-factor or two-factor ANOVA was carried out for measurement of head shake, rearing and horizontal locomotor activity. The Dunnett test or Neuman-Keuls test was used for the one-factor or two-factor ANOVAs, respectively. The effect of the adenosine $\mathrm{A}_{1}$ receptor agonist CHA was assessed using a between-subject design where a different group of rats were used for each dose $(n=8)$. The effect of the adenosine $A_{1}$ receptor antagonist DPCPX/vehicle with DOI/vehicle was tested using a with-in subject design $(\mathrm{n}=10)$ and a repeated measures ANOVA. The interaction of the adenosine $\mathrm{A}_{1}$ receptor antagonist DPCPX and the adenosine $\mathrm{A}_{1}$ receptor agonist $\mathrm{CHA}$ with respect to behavior induced by DOI was assessed using a between-subject design $(n=10)$. The level of significance was set for $\mathrm{p}<0.05$.

\subsection{Drugs}

Doses were calculated on the basis of the salt forms. The drugs were dissolved in saline, neutralized to a $\mathrm{pH} \sim 7.4$, and injected IP in a volume of $1 \mathrm{ml} / \mathrm{kg}$ body weight. The adenosine $\mathrm{A}_{1}$ receptor agonist $\mathrm{CHA}\left(\mathrm{N}^{6}\right.$-cyclohexyladenosine) and the adenosine $\mathrm{A}_{1}$ receptor antagonist DPCPX (8-cyclopentyl-1,3-dimethylxanthine) were purchased from Sigma-Aldrich (St. Louis, $\mathrm{MO}$ ) and Tocris (Ballwin, $\mathrm{MO}$ ), respectively. The $5-\mathrm{HT}_{2 \mathrm{~A} / 2 \mathrm{~B} / 2 \mathrm{C}}$ receptor partial agonist DOI, ( \pm )-2,5-dimethoxy-4-iodoamphetamine hydrochloride, was purchased from Research Biochemicals International (Natick, MA). At least a two week interval occurred between successive DOI injections to minimize tachyphylaxis of the DOI-induced head shakes. A dose of DOI $(1.25 \mathrm{mg} / \mathrm{kg}$, ip) producing a near-maximum of head shakes over a $30 \mathrm{~min}$ period was chosen for experiments testing suppression of head shakes by CHA (Gewirtz and Marek, 2000). DOI-induced head shakes increase in a monotonic dose-dependent manner through 9 $\mathrm{mg} / \mathrm{kg}$ using Sprague-Dawley rats (Pranzatelli, 1990). DPCPX/vehicle, CHA/vehicle and DOI/ vehicle were administered 30,15 and $0 \mathrm{~min}$, respectively, prior to beginning the $30 \mathrm{~min}$ observation period.

\section{Results}

\subsection{The adenosine $A_{1}$ receptor agonist $C H A$ suppresses $D O I-i n d u c e d$ head shakes}

The adenosine $A_{1}$ receptor agonist CHA (31.3-125 $\mu \mathrm{g} / \mathrm{kg}$, i.p.) suppressed DOI-induced head shakes in a dose-dependent manner $(F(3,28)=4.44, p<0.05$; Fig. 1). The 62.5 and the $125 \mu \mathrm{g} /$ $\mathrm{kg}$ CHA dose conditions combined with DOI were significantly different from DOI $(1.25 \mathrm{mg} /$ $\mathrm{kg}$ ) alone ( $\mathrm{p}<0.05$ and $\mathrm{p}<0.01$, respectively, Newman-Keuls test). CHA (31.3-125 $\mu \mathrm{g} / \mathrm{kg}$, i.p.) also suppressed the frequency of rearing enhanced by DOI in a dose-dependent manner ( $F$ $(3,28)=11.32$, $p<0.001 ;$ Fig. 1$)$. The frequency of rearing was significantly decreased when rats were treated with each dose condition ( $\mathrm{p}<0.01$, Newman-Keuls test). A trend for CHA in reducing locomotion in DOI-treated rats was also found $(\mathrm{F}(3,28)=2.81, \mathrm{p}=0.058$, not shown). DOI tended to double locomotor activity, although only a trend was found when comparing DOI $(1.25 \mathrm{mg} / \mathrm{kg})$ vs vehicle $(\mathrm{t}(7)=2.095, \mathrm{p}=0.074$, not shown $)$. 
No spontaneous head shakes were observed in these rats over the 30 min observation periods used in the absence of DOI. However, CHA (31.3-125 $\mu \mathrm{g} / \mathrm{kg}$ ) did suppress basal levels of rearing behavior $(F(3,28)=3.33$, $p<0.05$; Fig. 1$)$, with significant effects only at the 31.3 and $62.5 \mu \mathrm{g} / \mathrm{kg}$ dose levels $(\mathrm{p}<0.05$ and $\mathrm{p}<0.01$, respectively). CHA did not alter the basal horizontal locomotor activity $(F(3,28)=1.75, p>0.1$, not shown $)$.

\subsection{The adenosine $A_{1}$ receptor antagonist DPCPX enhances DOI-induced head shakes}

The adenosine $A_{1}$ receptor antagonist DPCPX (10 mg/kg, i.p.) enhanced head shakes induced by a lower DOI dose $(0.625 \mathrm{mg} / \mathrm{kg}$, i.p.; Fig. 2) than the first experiment. A significant effect was observed for DPCPX $(\mathrm{F}(1,9)=6.93, \mathrm{p}<0.05)$, DOI $(\mathrm{F}(1,9)=105.0, \mathrm{p}<0.001)$, and the interaction between DPCPX and DOI $(\mathrm{F}(1,9)=6.93, \mathrm{p}<0.05)$. DPCPX nearly doubled the frequency of DOI-induced head shakes ( $\mathrm{p}<0.01$, Newman-Keuls test). In contrast to this significant interaction, neither the adenosine $\mathrm{A}_{1}$ receptor antagonist factor nor the interaction factor between the $A_{1}$ receptor antagonist and DOI were significant for either rearing behavior or forward locomotion (not shown).

\subsection{DPCPX reverses the suppressant action of CHA on DOI-induced head shakes}

The adenosine $A_{1}$ receptor antagonist DPCPX (1.25-20 mg/kg, i.p.) blocked the suppressant action of CHA $(62.5 \mu \mathrm{g} / \mathrm{kg}$, i.p.) on DOI $(1.25 \mathrm{mg} / \mathrm{kg}$, i.p.)-induced head shakes in a dosedependent manner $(\mathrm{F}(5,53)=10.09, \mathrm{p}<0.001$, Fig. 3$)$. CHA suppressed DOI-induced head shakes by $83 \%$ ( $\mathrm{p}<0.001$, Newman-Keuls test) while each DPCPX dose significantly reversed the suppressant action of CHA on DOI-induced head shakes ( $\mathrm{p}<0.05$ for the 1.25 and $5 \mathrm{mg} / \mathrm{kg}$ dose, $\mathrm{p}<0.01 \mathrm{for}$ the $10 \mathrm{mg} / \mathrm{kg}$ dose, and $\mathrm{p}<0.001$ for the $20 \mathrm{mg} / \mathrm{kg}$ dose). While CHA suppressed rearing that was increased by DOI, a dose-dependent reversal by DPCPX was not observed.

\section{Discussion}

This is the first known demonstration that activation of adenosine $\mathrm{A}_{1}$ receptors, potentially by suppressing glutamate release in the prefrontal cortex and associated limbic regions, blocks the behavioral effect of a serotonergic hallucinogen used as a preclinical psychosis screen. The demonstration that acute administration of phenethylamine hallucinogens and other 5- $\mathrm{HT}_{2 \mathrm{~A}}$ receptor agonists into the prelimbic region of the rodent medial prefrontal cortex induces head shakes (Willins and Meltzer, 1997) is particularly important for a number of reasons. First, the DOI-induced head shake response is suppressed or enhanced by drugs which decrease or increase glutamate release, respectively, by acting on mGlu2 receptor autoreceptors (Benneyworth et al., 2007; Gewirtz and Marek, 2000; Klodzinska et al., 2002). Second, two different selective 5- $\mathrm{HT}_{2 \mathrm{~A}}$ receptor antagonists were found to possess modest antipsychotic effects in large multi-centered studies intermediate between placebo and haloperidol (Marder, 1999; Meltzer et al., 2004). This raises the possibility that the prefrontal cortex may be an important component of the circuitry mediating the antipsychotic responses observed with the mGlu2/3 receptor agonist prodrug $\mathrm{LY} 2140023$ and the $5-\mathrm{HT}_{2 \mathrm{~A}}$ receptor antagonists. In addition to $\mathrm{mGlu} 2 / 3$ receptor agonists and adenosine $\mathrm{A} 1$ receptor agonists both suppressing DOI-induced head shakes, activation of both adenosine $A_{1}$ receptors and mGlu2 receptors is known to suppress excitatory synaptic currents induced by $5-\mathrm{HT}_{2 \mathrm{~A}}$ receptor activation in the rat or mouse medial prefrontal cortex using slice preparations (Benneyworth et al., 2007; Klodzinska et al., 2002; Marek et al., 2000; Stutzman et al., 2001; Zhai et al., 2003).

These results extend previous preclinical in vivo research suggesting antipsychotic properties for adenosine $\mathrm{A}_{1}$ receptor agonists (Andine et al., 1999; Browne and Welch, 1982; Florio et al., 1998; Gotoh et al., 2002; Jain et al., 1995; Sills et al., 1999). Serotonergic hallucinogens as a pharmacological model for psychosis actually predated the use of non-competitive NMDA 
receptor antagonists or amphetamine/methamphetamine (Shaw and Woolley, 1956; Woolley and Shaw, 1954). Head shakes/head twitches induced by activation of 5- $\mathrm{HT}_{2 \mathrm{~A}}$ receptors in rodents has been one of the most commonly used preclinical behavioral models to back translate the psychotomimetic effects of LSD, mescaline and psilocybin analogues. Adenosine $\mathrm{A}_{1}$ receptor agonists, like $\mathrm{mGlu} 2 / 3$ receptor agonists are capable of suppressing the presumed psychotomimetic effects in rodents of all three major classes of challenge agents, noncompetitive NMDA receptor antagonists, amphetamine and serotonergic hallucinogens (Heffner et al., 1989; Andine et al., 1999; Gewirtz and Marek, 2000; Rorick-Kehn et al., 2007). This sharing of psychopharmacological effects between adenosine A1 receptor agonists and $\mathrm{mGlu} 2 / 3$ receptor agonists is especially poignant given the clinical observations that a prodrug for a mGlu2/3 receptor agonist improved both the positive and negative symptoms of schizophrenia in a double-blind, placebo-controlled study (Patil et al., 2007).

Involvement of prefrontal cortical $5-\mathrm{HT}_{2 \mathrm{~A}}$ receptors in these effects is supported by previous studies demonstrating that (1) activation of 5- $\mathrm{HT}_{2 \mathrm{~A}}$ receptors in the rat $\mathrm{PFC}$ alone is sufficient to induce head shakes and (2) a rescue of forebrain (prefrontal cortex, neocortex and claustrum) $5-\mathrm{HT}_{2 \mathrm{~A}}$ receptors is sufficient to support hallucinogen-induced head twitches in a mouse strain where hallucinogen-induced head twitches had been lost following constitutive disruption of 5- $\mathrm{HT}_{2 \mathrm{~A}}$ receptors (Gonzalez-Maeso et al., 2007; Willins and Meltzer, 1997). Furthermore, both electrophysiological and in vivo dialysis experiments have suggested that activation of mGlu2 receptors within the $\mathrm{mPFC}$ suppresses glutamate release induced by $5-\mathrm{HT}_{2 \mathrm{~A}}$ receptor activation (Benneyworth et al., 2007; Marek et al., 2001; Marek et al., 2000; Muschamp et al., 2004).

At a more fundamental level, the constellation of shared electrophysiological, biochemical and behavioral effects between adenosine $A_{1}$ receptor agonists and $\mathrm{mGlu} 2 / 3$ receptor agonists or mGlu2 potentiators emphasizes similar biological roles played by mGlu2 heteroceptors and adenosine $\mathrm{A}_{1}$ heteroceptors (Fredholm and Dunwiddie, 1988; Goodman et al., 1983; Schoepp, 2001). For example, activation of mGlu 2 receptors and adenosine $A_{1}$ receptors suppresses glutamate release from thalamocortical pathways (Fontanez and Porter, 2006; Marek et al., 2001). The plethora of behavioral effects predicting antipsychotic action for the activation of adenosine $A_{1}$ heteroceptors and $m$ Glu 2 receptors may also involve a wider limbic-related distribution of these receptors where they may play similar roles.

Electrophysiological studies in the $\mathrm{mPFC}$ are consistent with the hypothesis that adenosine $\mathrm{A}_{1}$ receptors suppress glutamate release induced by $5-\mathrm{HT}_{2 \mathrm{~A}}$ receptors in a fashion similar to mGlu2 receptor activation. Given (1) the similarity between the effects of mGlu 2 receptor activation and adenosine $\mathrm{A}_{1}$ receptor activation in the $\mathrm{PFC}$; (2) the similar laminar distribution of rodent $5-\mathrm{HT}_{2 \mathrm{~A}}$ receptors, mGlu2 receptors and adenosine $\mathrm{A}_{1}$ receptors (Fastbom et al., 1987; Lopez-Gimenez et al., 1997; Marek et al., 2001; Marek et al., 2008; Marek et al., 2000), and (3) the suggestion that $5-\mathrm{HT}_{2 \mathrm{~A}}$ and $\mathrm{mGlu} 2$ receptors interact via a molecular complex (Gonzalez-Maeso et al., 2008), then the presence or absence of a molecular complex between $5-\mathrm{HT}_{2 \mathrm{~A}}$ and adenosine $\mathrm{A}_{1}$ receptors may be important for evaluating this new theory postulated to explain physiological interactions between $5-\mathrm{HT}_{2 \mathrm{~A}}$ and $\mathrm{mGlu} 2$ receptors of relevance for psychosis and antipsychotic drug effects. Conversely, activation of a number of $\mathrm{G}_{\mathrm{q}}$-linked GPCRs acts similar to 5- $\mathrm{HT}_{2 \mathrm{~A}}$ receptors at inducing spontaneous 5-HT-induced EPSCs (e.g., $\alpha_{1}$-adrenergic, orexin-2, neurokinin-3, and mGlu5 receptors). These $\mathrm{G}_{\mathrm{q}}$-linked GPCRs might be expected to similarly interact with glutamatergic autoreceptors (mGlu2, mGlu4, mGlu8) and class A GPCR heteroceptors (adenosine $\mathrm{A}_{1}$ heteroceptors and u-opioid heteroceptors) similar to the proposed interaction of $5-\mathrm{HT}_{2 \mathrm{~A}}$ and $\mathrm{mGlu} 2$ receptors. It is also conceivable that the effects of adenosine $\mathrm{A}_{1}$ receptor agonists might be directly acting on other receptor that also oppose the effects of $5-\mathrm{HT}_{2 \mathrm{~A}}$ receptors such as $5-\mathrm{HT}_{1 \mathrm{~A}}$ receptors $(\mathrm{Zgombick}$ et al., 1989). However, this type of relationship would not appear as parsimonious as the 
alternative hypothesis that a number of Gi/Go-coupled GPCRs similarly oppose the effects of $5-\mathrm{HT}_{2 \mathrm{~A}}$ receptor activation by virtue of sharing aspects of post-receptor transduction pathways.

Other brain regions may mediate the effects of systemic administration of adenosine $A_{1}$ receptor agonists and antagonists on DOI-induced head shakes. Adenosine $\mathrm{A}_{1}$ receptor activation may suppress neurotransmitter release in a number of regions associated with neuropsychiatric illness ranging from the PFC, hippocampus, the striatum, thalamus, and brainstem nuclei associated with attention and arousal via a number of mechanisms (Fredholm and Dunwiddie, 1988; Ochiishi et al., 1999; Rivkees et al., 1995). The distribution of mGlu2 receptor mRNA and protein in limbic-related regions is similar to the pattern observed for adenosine $A_{1}$ receptor $m R N A$ and protein.

The present results may be relevant to understanding additional domains of behavior which might be impacted by modulation of adenosine $A_{1}$ receptors. Previously, drugs which block adenosine $A_{1}$ receptors such as caffeine and PD 116,600 have been found to impair performance of rats on a differential-reinforcement-of-low rate (DRL) 72-s operant schedule consistent with an enhancement of impulsivity (Marek et al., 1993). Activation of 5-HT2A receptors has been found to increase motoric impulsivity while blockade of $5-\mathrm{HT}_{2 \mathrm{~A}}$ receptors appears to enhance the ability of animals to wait before making a response when performing on DRL 72-s schedules (Ardayfio et al., 2008; Carli et al., 2004; Winstanley et al., 2004). Given the growing literature supporting these findings, determining the effects of adenosine $\mathrm{A}_{1}$ receptor agonists and mGlu2 receptor potentiators or $\mathrm{mGlu} 2 / 3$ receptor agonists in tasks assessing dysfunction of the prefrontal cortex is of great heuristic and potential therapeutic interest.

\section{Conclusions}

The present study provides a third psychotomimetic animal model predicting antipsychotic action for adenosine $\mathrm{A}_{1}$ receptor agonists. Adenosine $\mathrm{A}_{1}$ receptor agonists have a primary role in suppressing glutamate release from heteroceptors from axons throughout the forebrain, including the prefrontal cortex. These results are consistent with the hypothesis that drugs which suppress glutamate release from dysfunctional limbic circuits, such as mGlu2 receptor agonists or potentiators, will be useful antipsychotic drugs.

\section{Acknowledgements}

These experiments were performed in the Department of Psychiatry at the Yale University School of Medicine and the Ribicoff Research Facilities of the Connecticut Mental Health Center. Support from the National Institutes of Health Grants RO1 MH62186 and K08 MH01551 and the state of Connecticut is gratefully acknowledged. I also thank Allyson Abo, Sara Heron, Angela Keene, and Kim Reiss for technical assistance.

\section{References}

Andine P, Widermark N, Axelsson R, Nyberg G, Olofsson U, Martensson E, Sandberg M. Characterization of MK-801-induced behavior as a putative rat model of psychosis. J. Pharmacol. Exp. Ther 1999;290:1393-1408. [PubMed: 10454519]

Ardayfio PA, Benvenga MJ, Chaney SF, Love PL, Catlow J, Swanson SP, Marek GJ. The 5hydroxytryptamine $2 \mathrm{~A}$ receptor antagonist R-(+)-a-(2,3-dimethoxyphenyl)-1-[2-(4-fluorophenyl) ethyl-4-piperidinemethanol (M100907) attenuates impulsivity after both drug-induced disruption (dizocilpine) and enhancement (antidepressant drugs) of differential-reinforcement-of-low-rate 72-s behavior in the rat. J. Pharmacol. Exp. Ther 2008;327:891-897. [PubMed: 18772320]

Benneyworth MA, Xiang Z, Smith RL, Garcia EE, Conn PJ, Sanders-Bush E. A selective positive allosteric modulator of metabotropic glutamate receptor subtype 2 blocks a hallucinogenic drug model of psychosis. Mol. Pharmacol 2007;72:477-484. [PubMed: 17526600] 
Brand A, Vissiennon Z, Eschke D, Nieber K. Adenosine $\mathrm{A}_{1}$ and $\mathrm{A}_{3}$ receptors mediate inhibition of synaptic transmission in rat cortical neurons. Neuropharmacol 2001;40:85-95.

Browne RG, Welch WM. Stereoselective antagonism of phencyclidine's discriminative properties by adenosine receptor agonists. Science 1982;217:1157-1159. [PubMed: 6287578]

Bruns RF, Fergus JH, Badger EW, Bristol JA, Santay LAH, J D, Hays SJ, Huang CC. Binding of the $\mathrm{A}_{1}$-selective adenosine antagonist 8-cyclopentyl-1,3-diproprylxanthine to rat brain membranes. Naunyn Schmiedebergs Arch. Pharmacol 1987;335:59-63. [PubMed: 3574492]

Carli M, Baviera M, Invernizzi RW, Balducci C. The serotonin 5- $\mathrm{HT}_{2 \mathrm{~A}}$ receptors antagonist M100907 prevents impairment in attentional performance by NMDA receptor blockade in the rat prefrontal cortex. Neuropsychopharmacol 2004;29:1637-1647.

Cartmell J, Monn JA, Schoepp DD. Attenuation of specific PCP-evoked behaviors by the potent mGlu2/3 receptor agonist, LY379268 and comparision with the atypical antipsychotic, clozapine. Psychopharmacol 2000a; 148:423-429.

Cartmell J, Perry KW, Salhoff CR, Monn JA, Schoepp DD. The potent, selective mGlu2/3 receptor agonist LY379268 increases extracellular levels of dopamine, 3,4-dihydroxyphenylacetic acid, homovanillic acid, and 5-hydroxyindole3-acetic acid in the medial prefrontal cortex of the freely moving rat. J. Neurochem. 2000bin press

Dunayevich E, Erickson J, Levine L, Landbloom R, Schoepp DD, Tollefson GD. Efficacy and tolerability of an mGlu2/3 agonist in the treatment of generalized anxiety disorder. Neuropsychopharmacol 2008;33:1603-1610.

Fastbom J, Pazos A, Palacios JM. The distribution of adenosine A1 receptors and 5'-nucleotidase in the brain of some commonly used experimental animals. Neurosci 1987;22:813-826.

Florio C, Prezioso A, Papaioannou A, Vertua R. Adenosine A1 receptors modulate anxiety in CD1 mice. Psychopharmacol 1998;136:311-319.

Fontanez DE, Porter JT. Adenosine A1 receptors decrease thalamic excitation of inhibitory and excitatory neurons in the barrel cortex. Neurosci 2006;137:1177-1184.

Fredholm BB, Dunwiddie TV. How does adenosine inhibit transmitter release. Trends Pharmacol Sci 1988;9:130-134. [PubMed: 2907698]

Galici R, Echemendia NG, Rodriquez AL, Conn PJ. A selective allosteric potentiator of metabotropic glutamate (mGlu) 2 receptors has effects similar to an orthosteric $m$ Glu $2 / 3$ receptor agonist in mouse models predictive of antipsychotic activity. J. Pharmacol. Exp. Ther 2005;315:1181-1187. [PubMed: 16123306]

Gewirtz JC, Marek GJ. Behavioral evidence for interactions between a hallucinogenic drug and group II metabotropic glutamate receptors. Neuropsychopharmacol 2000;23:569-576.

Gonzalez-Maeso J, Ang RL, Yuen T, Chan P, Weisstaub NV, Lopez-Gimenez JF, Zhou M, Okawa Y, Callado LF, Milligan G, Gingrich JA, Filizola M, Meana JJ, Sealfon SC. Identification of a serotonin/ glutamate receptor complex implicated in psychosis. Nature 2008;452:93-97. [PubMed: 18297054]

Gonzalez-Maeso J, Weisstaub NV, Zhou M, Chan P, Ivic L, Ang R, Lira A, Bradley-Moore M, Ge Y, Zhou Q, Sealfon SC, Gingrich JA. Hallucinogens recruit specific cortical 5-HT 2 A receptor-mediated signalling pathways to affect behavior. Neuron 2007;53:439-452. [PubMed: 17270739]

Goodman RR, Kuhar MJ, Hester L, Snyder SH. Adenosine receptors: Autoradiographic evidence for their location on axon terminals of excitatory neurons. Science 1983;220:967-969. [PubMed: 6302841]

Gotoh L, Kawanami N, Nakahara T, Hondo H, Motomura K, Ohta E, Kanchiku I, Kuroki T, Hirano M, Uchimura $\mathrm{H}$. Effects of the adenosine $\mathrm{A} 1$ receptor agonist $\mathrm{N}^{6}$-cyclopentyladenosine on phencyclidine-induced behavior and expression of the immediate early genes in the discrete brain regions of rats. Mol. Brain Res 2002;100:1-12. [PubMed: 12008016]

Heffner TG, Wiley JN, Williams AE, Bruns RF, Coughenour LL, Downs DA. Comparison of the behavioral effects of adenosine agonists and dopamine antagonists in mice. Psychopharmacol 1989;98:31-37.

Higgins GA, Enderlin M, Haman M, Fletcher PJ. The 5-HT2A receptor antagonist M100,907 attenuates motor and 'impulsive-type' behaviors produced by NMDA receptor antagonism. Psychopharmacol 2003;170:309-319. 
Homayoun H, Jackson ME, Moghaddam B. Activation of metabotropic glutamate 2/3 receptors reverses the effects of NMDA receptor hypofunction on prefrontal cortex unit activity in awake rats. J. Neurophysiol 2005;93

Homayoun H, Moghaddam B. NMDA receptor hypofunction produces opposite effects on prefrontal cortex interneurons and pyramidal neurons. J. Neurosci 2007;27:11496-11500. [PubMed: 17959792]

Jain N, Kemp N, Adeyemo O, Buchanan P, Stone TW. Anxiolytic activity of adenosine receptor activation in mice. Br. J. Pharmacol 1995;116:2127-2133. [PubMed: 8640355]

Jodo E, Suzuki Y, Katayama T, Hoshino H-Y, Takeuchi S, Niwa S-I, Kayama Y. Activation of medial prefrontal cortex by phencyclidine is mediated via a hippocampal-prefrontal pathway. Cerebral Cortex 2004;15:663-669. [PubMed: 15342431]

Klodzinska A, Bijak M, Tokarski K, Pilc A. Group II mGlu receptor agonists inhibit behavioral and electrophysiological effects of DOI in mice. Pharmacol. Biochem. Behavior 2002;73:327-332.

Lopez-Gimenez JF, Mengod G, Palacios JM, Vilaro MT. Selective visualization of rat brain 5-HT2A receptors by autoradiography with $\left[{ }^{3} \mathrm{H}\right] \mathrm{MDL} 100,907$. Naunyn-Schmiedeberg's Arch. Pharmacol 1997;356:446-454. [PubMed: 9349630]

Marder SR. Limitations of dopamine-D2 antagonists and the search for novel antipsychotic strategies. Neuropsychopharmacol 1999;21(S6):S117-S121.

Marek GJ, Heffner TG, Richards JB, Shaughnessy RA, Li AA, Seiden LS. Effects of caffeine and PD 116,600 on the differential-reinforcement-of-low rate 72-s (DRL 72-s) schedule of reinforcement. Pharmacol. Biochem. Behav 1993;45:987-990. [PubMed: 8415842]

Marek GJ, Wright RA, Gewirtz JC, Schoepp DD. A major role for thalamocortical afferents in serotonergic hallucinogen receptor function in the rat neocortex. Neurosci 2001;105:379-392.

Marek GJ, Wright RA, Johnson BG, Fell M, Svensson K, Benvenga M, Chaney S, Schoepp DD, Monn J. Activation of mGlu2 receptors mediates the "antipsychotic-like" activity of mGlu2/3 receptor agonists in three psychotomimetic drug models and regional distribution of mGlu2 vs. mGlu3 receptors. Neuropharmacol 2008;55:608-609.

Marek GJ, Wright RA, Schoepp DD, Monn JA, Aghajanian GK. Physiological antagonism between 5hydroxytryptamine $2 \mathrm{~A}$ and group II metabotropic glutamate receptors in prefrontal cortex. J. Pharmacol. Exp. Ther 2000;292:76-87. [PubMed: 10604933]

Meltzer HY, Arvanitis L, Bauer D, Rein W, Group M-TS. Placebo-controlled evaluation of four novel compounds for the treatment of schizophrenia and schizoaffective disorders. Am. J. Psychiatry 2004;161:975-984. [PubMed: 15169685]

Moghaddam B, Adams BW. Reversal of phencyclidine effects by a group II metabotropic glutamate receptor agonists in rats. Science 1998;281:1349-1352. [PubMed: 9721099]

Muschamp JW, Regina MJ, Hull EM, Winter JC, Rabin RA. Lysergic acid diethylamide and (-)-2,5dimethoxy-4-methylamphetamine increase extracellular glutamate in rat prefrontal cortex. Brain Res 2004;1023:134-140. [PubMed: 15364028]

Ochiishi T, Chen L, Yukawa A, Saitoh Y, Sekino Y, Arai T, Nakata H, Miyamoto H. Cellular localization of adenosine A1 receptors in rat forebrain: Immunohistochemical analysis using adenosine A1 receptor-specific monoclonal antibody. J. Comp. Neurol 1999;411:301-316. [PubMed: 10404255]

Patil ST, Zhang L, Martenyi F, Lowe SL, Jackson KA, Andreev BV, Avedisova AS, Bardenstein LM, Gurovich IY, Morozova MA, Mosolov SN, Neznanov NG, Reznik AM, Smulevich AB, Tochilov VA, Johnson BG, Monn JA, Schoepp DD. Activation of mGlu2/3 receptors as a new approach to treat schizophrenia: a randomized Phase 2 clinical trial. Nature Medicine 2007;13:1103-1108.

Pranzatelli MR. Evidence for involvement of 5- $\mathrm{HT}_{2}$ and 5- $\mathrm{HT}_{1 \mathrm{C}}$ receptors in the behavioral effects of the 5-HT agonist 1-(2,5-dimethoxy-4-iodophenyl aminopropane)-2 (DOI). Neurosci. Lett 1990;115:74-80. [PubMed: 2216059]

Rivkees SA, Price SL, Zhou FC. Immunohistochemical detection of A1 adenosine receptors in rat brain with emphasis on localization in the hippocampal formation, cerebral cortex, cerebellum, and basal ganglia. Brain Res 1995;677:193-203. [PubMed: 7552243]

Rorick-Kehn LM, Johnson BG, Knitowski KM, Salhoff CR, Witkin JM, Perry KW, Griffey KI, Tizzano JP, Monn JA, McKinzie DL, Schoepp DD. In vivo pharmacological characterization of the structurally novel, potent, selective mGlu2/3 receptor agonist LY404039 in animal models of psychiatric disorders. Psychopharmacol 2007;193:121-136. 
Salvatore CA, Jacobson MA, Taylor HE, Linden J, Johnson RG. Molecular cloning and characterization of the human $A_{3}$ adenosine receptor. Proc. Natl. Acad. Sci. USA 1993;90:10365-10369. [PubMed: 8234299]

Schoepp DD. Unveiling the functions of presynaptic metabotropic glutamate receptors in the central nervous system. J. Pharmacol. Exp. Ther 2001;299:12-20. [PubMed: 11561058]

Scruggs JL, Schmidt D, Deutch AY. The hallucinogen 1-[2,5-dimethoxy-4-iodophenyl]-2-aminopropane (DOI) increases cortical extracellular glutamate levels in rats. Neurosci. Lett 2003;346:137-140. [PubMed: 12853103]

Shaw E, Woolley DW. Some serotoninlike activities of lysergic acid diethylamide. Science 1956;124:121-122. [PubMed: 13337360]

Sills TL, Azampanah A, Fletcher PJ. The adenosine $\mathrm{A}_{1}$ receptor agonist $\mathrm{N}^{6}$-cyclopentyladenosine blocks the disruptive effect of phencyclidine on prepulse inhibition of the acoustic startle response in the rat. Eur. J. Pharmacol 1999;369:325-329. [PubMed: 10225370]

Stutzman GE, Marek GJ, Aghajanian GK. Adenosine preferentially suppresses serotonin2A receptorenhanced excitatory postsynaptic currents in layer $\mathrm{V}$ neurons of the rat medial prefrontal cortex. Neurosci 2001;105:55-69.

Vollenweider FX, Leenders KL, Scharfetter C, Maguire P, Stadelmann O, Angst J. Positron emission tomography and fluorodeoxyglucose studies of metabolic hyperfrontality and psychopathology in the psilocybin model of psychosis. Neuropsychopharmacol 1997;16:357-372.

Willins DL, Meltzer HY. Direct injection of 5-HT2A receptor agonists into the medial prefrontal cortex produces a head-twitch response in rats. J. Pharmacol. Exp. Ther 1997;282:699-706. [PubMed: 9262333]

Winstanley CA, Theobald DEH, Dalley JW, Glennon JC, Robbins TW. 5-HT2A and 5-HT2C receptor antagonists have opposing effects on a measure of impulsivity: interactions with global 5-HT depletion. Psychopharmacol 2004;176:376-385.

Woolley DW, Shaw E. A biochemical and pharmacological suggestion about certain mental disorders. Proc. Natl. Acad. Sci., USA 1954;40:228-231. [PubMed: 16589461]

Zgombick JM, Beck SG, Mahle CD, Craddock-Royal B, Maayani S. Pertussis toxin-sensitive guanine nucleotide-binding protein(s) couple adenosine $\mathrm{A}_{1}$ and 5-hydroxytrytamine ${ }_{1 \mathrm{~A}}$ receptors to the same effector systems in rat hippocampus: Biochemical and electrophysiological studies. Mol. Pharmacol 1989;35:484-494. [PubMed: 2495434]

Zhai Y, George CA, Zhai J, Nisenbaum ES, Johnson MP, Nisenbaum LK. Group II metabotropic glutamate receptor modulation of DOI-induced c-fos mRNA and excitatory responses in the cerebral cortex. Neuropsychopharmacol 2003;28:45-52. 

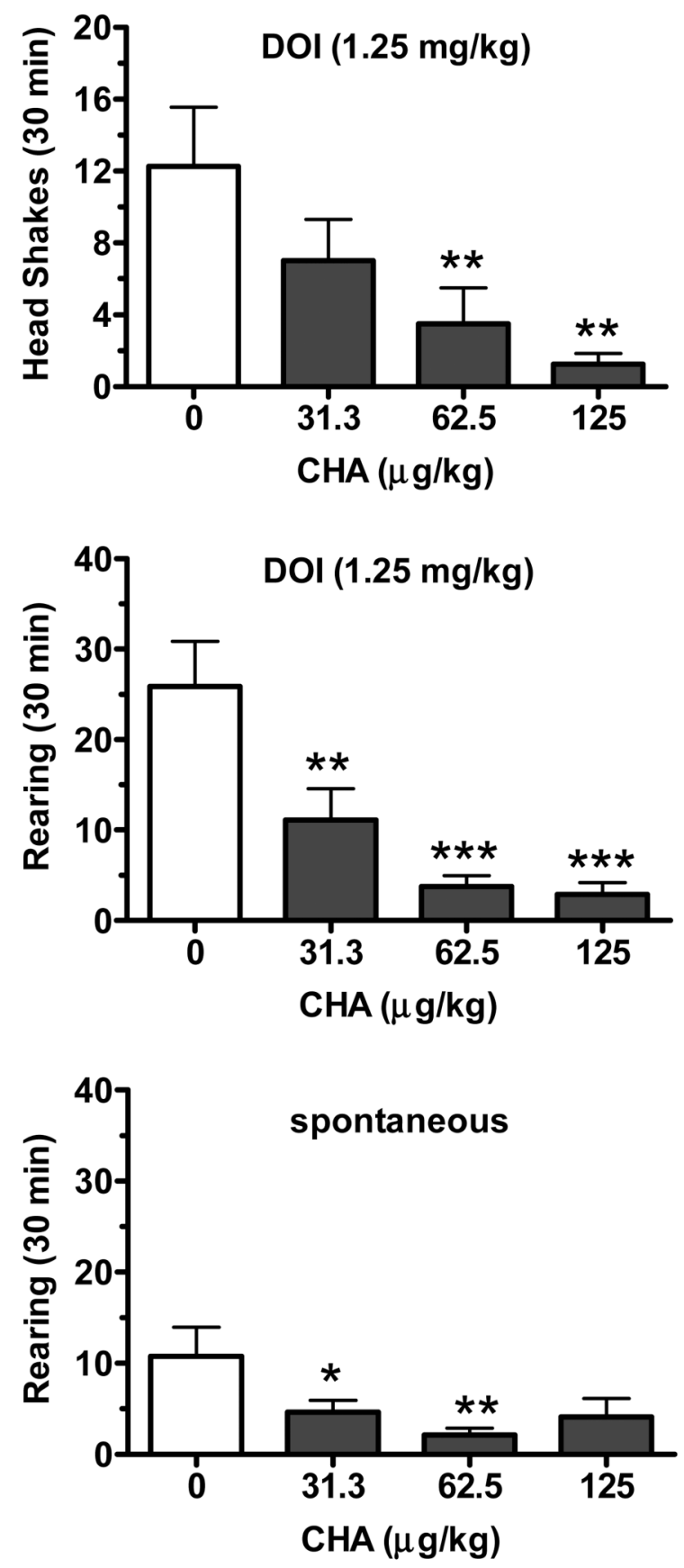

Fig. 1.

Dose-dependent suppression of DOI-induced head shakes and rearing by the adenosine $\mathrm{A}_{1}$ receptor agonist CHA (31.3-125 $\mu \mathrm{g} / \mathrm{kg}$, i.p.). The top panel displays the frequency of DOI $(1.25 \mathrm{mg} / \mathrm{kg}$, i.p.)-induced head shakes (mean $\pm \mathrm{SEM}) 30 \mathrm{~min}$ following treatment with either vehicle or CHA $(31.3,62.5,125 \mu \mathrm{g} / \mathrm{kg}$; $\mathrm{n}=8 /$ condition). In the absence of DOI, no head shakes were counted in rats similarly treated with vehicle or CHA (not shown) and observed for a 30 min period. The middle and lower panels display the frequency of rearing for the same rats under the same treatment conditions, except in the lower panel where DOI was not injected. * $\mathrm{p}<0.05 ; * * \mathrm{p}<0.01 ; * * * \mathrm{p}<0.001$ compared to the DOI/vehicle condition. 

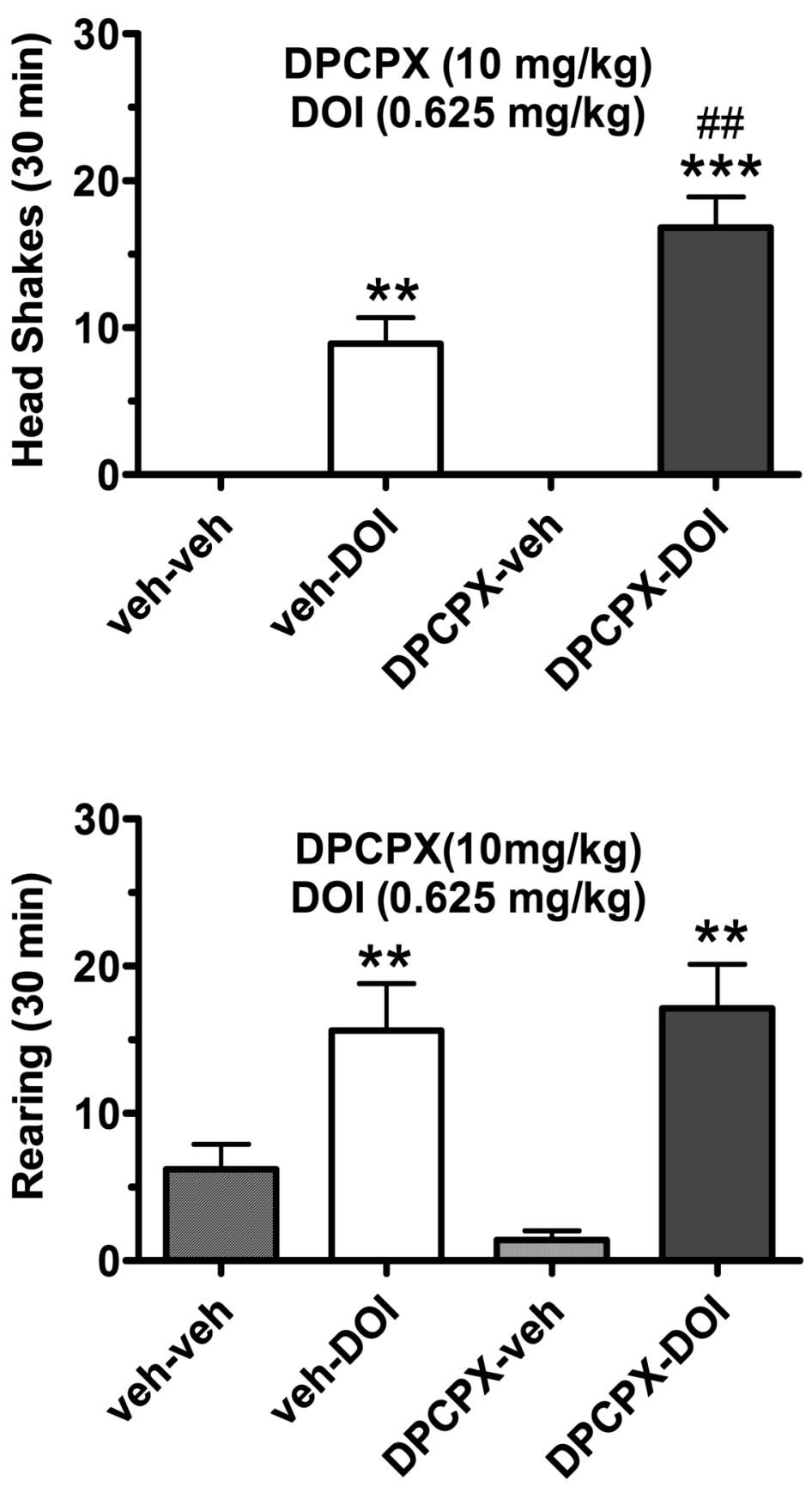

Fig. 2.

The adenosine $\mathrm{A}_{1}$ receptor antagonist DCPCX enhances DOI-induced head shakes. The top panel displays the frequency of DOI $(1.25 \mathrm{mg} / \mathrm{kg}$, i.p.)-induced head shakes (mean $\pm \mathrm{SEM})$ in the presence and absence of the DCPCX (10 mg/kg, i.p.; $\mathrm{n}=10)$. The bottom shows the absence of an effect of this DCPCX dose on rearing associated with DOI. 

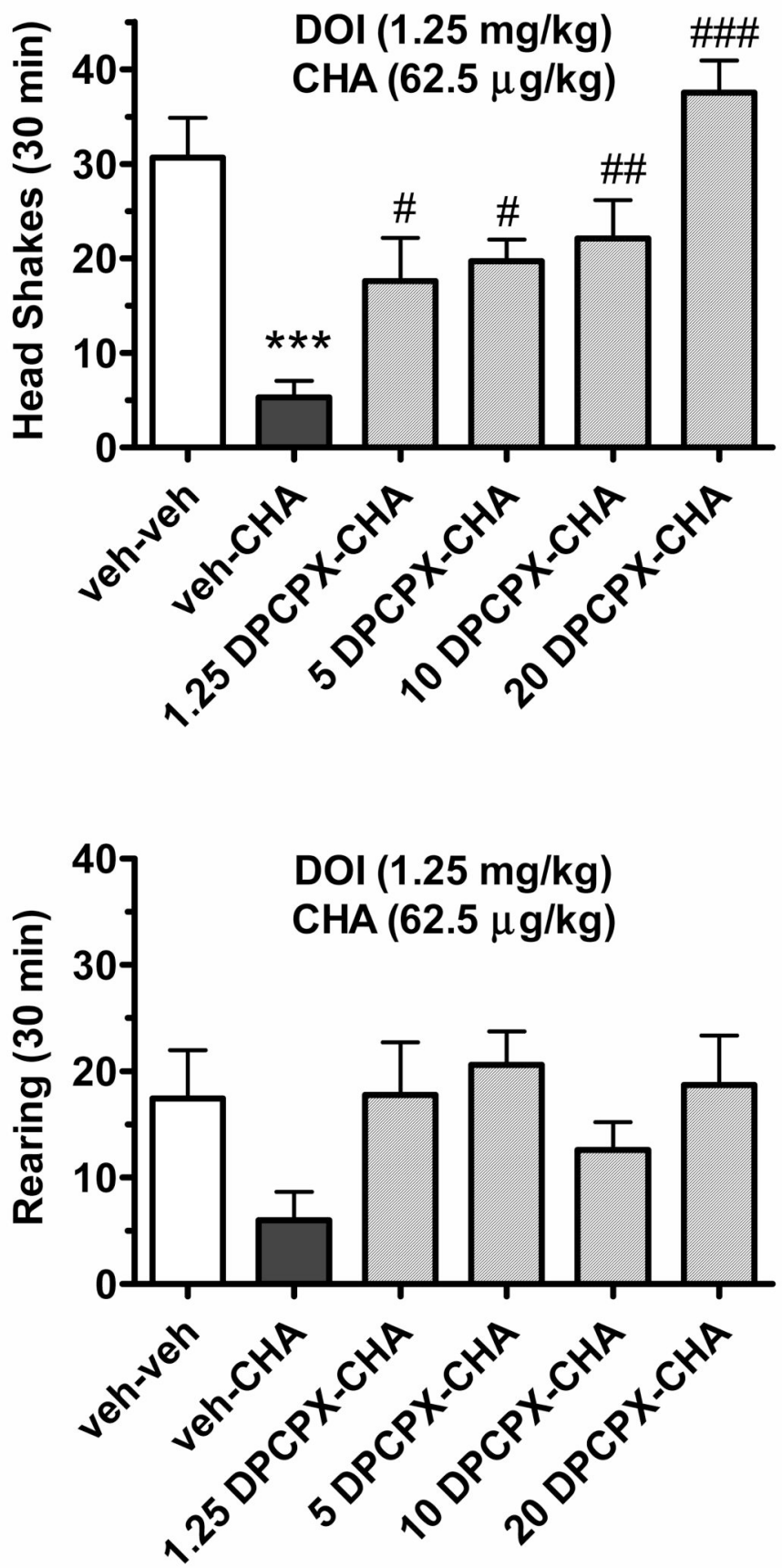

Fig. 3.

Dose-dependent attenuation by the adenosine $\mathrm{A}_{1}$ receptor antagonist DCPCX of the suppressant action of the adenosine $\mathrm{A}_{1}$ agonist CHA on DOI-induced head shakes. The top panel shows the frequency of DOI $(1.25 \mathrm{mg} / \mathrm{kg}$, ip)-induced head shakes in rats also treated with vehicle or CHA $(62.5 \mu \mathrm{g} / \mathrm{kg}$, i.p.) and either vehicle or DCPCX $(1.25-20 \mathrm{mg} / \mathrm{kg} ; \mathrm{n}=10 /$ condition). The bottom panel shows the frequency of rearing under similar treatment conditions where again, all rats received DOI treatment immediately prior to the observation period. * $\mathrm{p}<0.05$, compared to the vehicle-vehicle condition; \# $\mathrm{p}<0.05$, \#\# $\mathrm{p}<0.01$, \#\#\# $\mathrm{p}<0.001$ compared to the CHA-vehicle condition, respectively. 